Natalia Wiktorczyk ${ }^{1}$, Krzysztof Skowron ${ }^{1}$, Katarzyna Grudlewska ${ }^{1}$, Paweł Czobot ${ }^{3}$, Ewa WałeckaZacharska², Joanna Kwiecińska-Piróg ${ }^{1}$, Zbigniew Paluszak ${ }^{3}$, Eugenia Gospodarek-Komkowska ${ }^{1}$

${ }^{1}$ Department of Microbiology, Nicolaus Copernicus University in Toruń, Ludwik Rydygier Collegium Medicum, Bydgoszcz, Poland

2Department of Food Hygiene and Consumer Health, Wrocław University of Environmental and Life Sciences, Wrocław, Poland

${ }^{3}$ Department of Microbiology and Food Technology, UTP University of Science and Technology, Bydgoszcz, Poland

\title{
Effect of commercially available spices and herbs on the survival of Listeria monocytogenes and Salmonella Enteritidis
}

\author{
Corresponding author: \\ Krzysztof Skowron, \\ Department of Microbiology, \\ Nicolaus Copernicus University \\ in Toruń, Ludwik Rydygier Collegium \\ Medicum, 9 M. Skłodowskiej-Curie St. \\ 85-094 Bydgoszcz, Poland \\ e-mail: skowron238@wp.p
}

Medical Research Journal 2019

Volume 4, Number 1, 25-30

DOI: 10.5603/MRJ.a2019.0003

Copyright (C) 2019 Via Medica

ISSN 2451-2591

\begin{abstract}
Background: Currently, natural food preservation methods are explored, one of which includes the use of herbs and spices.

Methods: The study assessed the effect of herbs and spices; either opened directly before the test or opened and stored for three months; on the survival of L. monocytogenes and $S$. Enteritidis bacilli, isolated from meat. Moreover, the microbiological purity of the investigated herbs and spices was evaluated. The research consisted of the analysis of inhibition zone patterns around the wells with spice pulp after the incubation period.

Results: Varied influence of herbs and spices on the survival of bacilli was reported, depending on the species. The strongest impact against $L$. monocytogenes, among freshly opened spices, had: granulated garlic (38.63 mm), whole cloves $(28.87 \mathrm{~mm})$, savoury $(22.25 \mathrm{~mm})$, ground cinnamon $(22.13 \mathrm{~mm})$, ground ginger $(18.75 \mathrm{~mm})$. As for $\mathrm{S}$. Enteritidis, in the group of freshly opened spices, the strongest effect was found for: granulated garlic $(37.25 \mathrm{~mm})$, whole cloves $(31.50 \mathrm{~mm})$, and ground cinnamon $(18.16 \mathrm{~mm})$. It was reported that the storage of open spices caused a decrease in antimicrobial activity against L. monocytogenes, except for cloves, oregano, hot pepper, chilli, sage and turmeric. In the case of $S$. Enteritidis, the following stored spices were not effective: cinnamon, ground black pepper, sage, oregano, basil, tarragon, marjoram, rosemary, coriander, green mint, hot pepper, chilli, curry.

Conclusions: It was confirmed, that herbs and spices, because of its antimicrobial activity can be used, e.g. for food preservation, minimizing the amount of chemical additives applied to the product and extending its shelf-life.

Key words: L. monocytogenes, S. Enteritidis, spices, herbs, meat, food preservation
\end{abstract}

Med Res J 2019; 4 (1): 25-30

\section{Introduction}

Both herbs and spices are an important ingredient of most dishes. They have also application in cosmetology and medicine. Spices include leaves (mint, rosemary), flowers (cloves), bulbs (garlic, onion), fruit (cumin, red chilli), stems (cinnamon) and rhizomes (ginger) of plants. All spices obtained from plants were considered safe for the consumer (GRAS, Generally Recognized As Safe) [1]. It is assumed that over 100 different spices are produced globally. Asia is the leader in its production [2]. Both herbs and spices are a rich source of bioactive chemical compounds, such as vitamins, macro- and micronutrients, glycosides, alkaloids, tannins, flavonoids, phenols, organic acids and saponins. Bioactive substances of spices and herbs can be classified into volatile and non-volatile compounds, the former being mostly responsible for the antimicrobial properties of spices. The volatile active compounds of spices were divided into four groups: terpenes, terpenoids, phenylpropenes and "other”, e.g. degradation products [3, 4].

Food poisonings and infections are a serious public health problem, both for consumer and food producers [4]. Current food preservation technologies; 
chemical preservatives, heat treatment, packaging in a modified atmosphere or vacuum packaging; are not fully effective in the elimination of certain bacteria, such as L. monocytogenes in food products [5]. Meat and dairy products are the most susceptible to microbial contamination [4]. Over 1340 plants with proven antimicrobial activity have been identified, from which over 30,000 compounds have been isolated. It is difficult to determine the sensitivity of microorganisms to herbs and spices. Their effectiveness depends on the $\mathrm{pH}$, temperature and amount of oxygen during storage and the concentration of essential oils and active compounds (conditions of plants growth and harvest) [5]. Active substances can affect the microbial structure; cell membrane or genetic material; and metabolism; e.g. cause disorders in enzymes synthesis and function [3, 6, 7]. Gram-negative bacteria, such as Escherichia coli and S. Enteritidis, are less susceptible to the action of antimicrobials; the presence of lipopolysaccharide is bounding the diffusion of phenolic compounds; than Gram-positive bacteria (Staphylococcus aureus, L. monocytogenes, Bacillus cereus) due to the direct interaction of their cellular membrane with lipophilic active compounds of herbs and spices [1].

The aim of the study was to assess the impact of commercially available herbs and spices; freshly open or opened and stored for three months at room temperature; on the survival of $L$. monocytogenes and $S$. Enteritidis strains isolated from meat. Moreover, the microbiological purity of herbs and spices used in the study was evaluated.

\section{Materials and methods}

\section{Materials}

The biological material included eight strains of $L$. monocytogenes and eight strains of $S$. Enteritidis isolated from meat, obtained from the collection of the Department of Microbiology of L. Rydygier Collegium Medicum, UMK in Bydgoszcz.

The study included 20 commercially available herbs and spices (chili, hot pepper, sweet pepper, curry, turmeric, cinnamon, whole cloves, ground black pepper, ground ginger, granulated garlic, green mint, sage, thyme, basil, oregano, savory, marjoram, tarragon, coriander, rosemary) in two variants: freshly open or opened and stored for three months. All spices and herbs used in the study came from a single producer available on the Polish market.

\section{Influence of spices and herbs on the survival of strains tested}

In the first step, spices were prepared. For this purpose, $1 \mathrm{~g}$ of the seasoning was weighed into a sterile
Petri dish. Next, sterile water was added in a volume allowing to obtain the so-called pulp.

The impact of herbs and spices on the microbes survival was evaluated by surface culturing of bacterial suspensions ( 0.5 on the MacFarland scale) in a buffered saline solution (Avantor) on the Müeller Hinton Agar with $5.0 \%$ equine blood and $20 \mathrm{mg} \cdot \mathrm{l}^{-1} \beta$-NAD (bioMérieux) - L. monocytogenes, or the Müeller Hinton Agar (bioMérieux) $-S$. Enteritidis. Next, the tested spice pulp $(0.1 \mathrm{~g})$ was applied to the wells drilled with a sterile cork borer. The plates were incubated for $24 \mathrm{~h}$ at $37^{\circ} \mathrm{C}$. After the incubation period, zones of growth inhibition [mm] were measured around the wells with the spices.

\section{Evaluation of microbiological purity of spices and herbs}

The microbiological purity of all 20 spices and herbs tested (opened immediately before the study, and opened and stored for three months at room temperature) was evaluated in accordance with the Polish norm PN-A-86967 [8]. After the incubation period, the species identification of the grown colonies was performed using the MALDI TOF MS apparatus (Bruker) in accordance with the manufacturer's instruction.

\section{Statistical analysis}

The statistical analysis was performed using Statistica 12.0 PL (StatSoft) software. To evaluate the differences in microbiocidal activity, depending on the type of spices and the time that has elapsed since their opening, the post-hoc Tukey test was used. The differences were considered significant at the probability level $p<0.05$.

\section{Results}

It was found that all spices and herbs opened immediately before the study demonstrated activity against $L$. monocytogenes (Fig. 1). It was also reported that granulated garlic $(37.25 \mathrm{~mm})$, whole cloves $(31.50 \mathrm{~mm})$, ground cinnamon $(18.16 \mathrm{~mm})$, ground ginger $(15.88 \mathrm{~mm})$, and hot pepper $(11.38 \mathrm{~mm})$ had the strongest antimicrobial activity against $S$. Enteritidis in the group of freshly opened spices (Fig. 2). As for $L$. monocytogenes, the strongest effect among the freshly open spices had: granulated garlic (38.63 $\mathrm{mm})$, whole cloves $(28.87 \mathrm{~mm})$, savoury $(22.25 \mathrm{~mm})$, ground cinnamon $(22.13 \mathrm{~mm})$, and ground ginger $(18.75 \mathrm{~mm})$ (Fig. 1). In the group of spices opened immediately before the study, significant differences were found for granulated garlic (Fig. 1). As for basil opened immediately prior to the study, activity against one strain of $L$. monocytogenes was found (Fig. 1). Among the freshly 


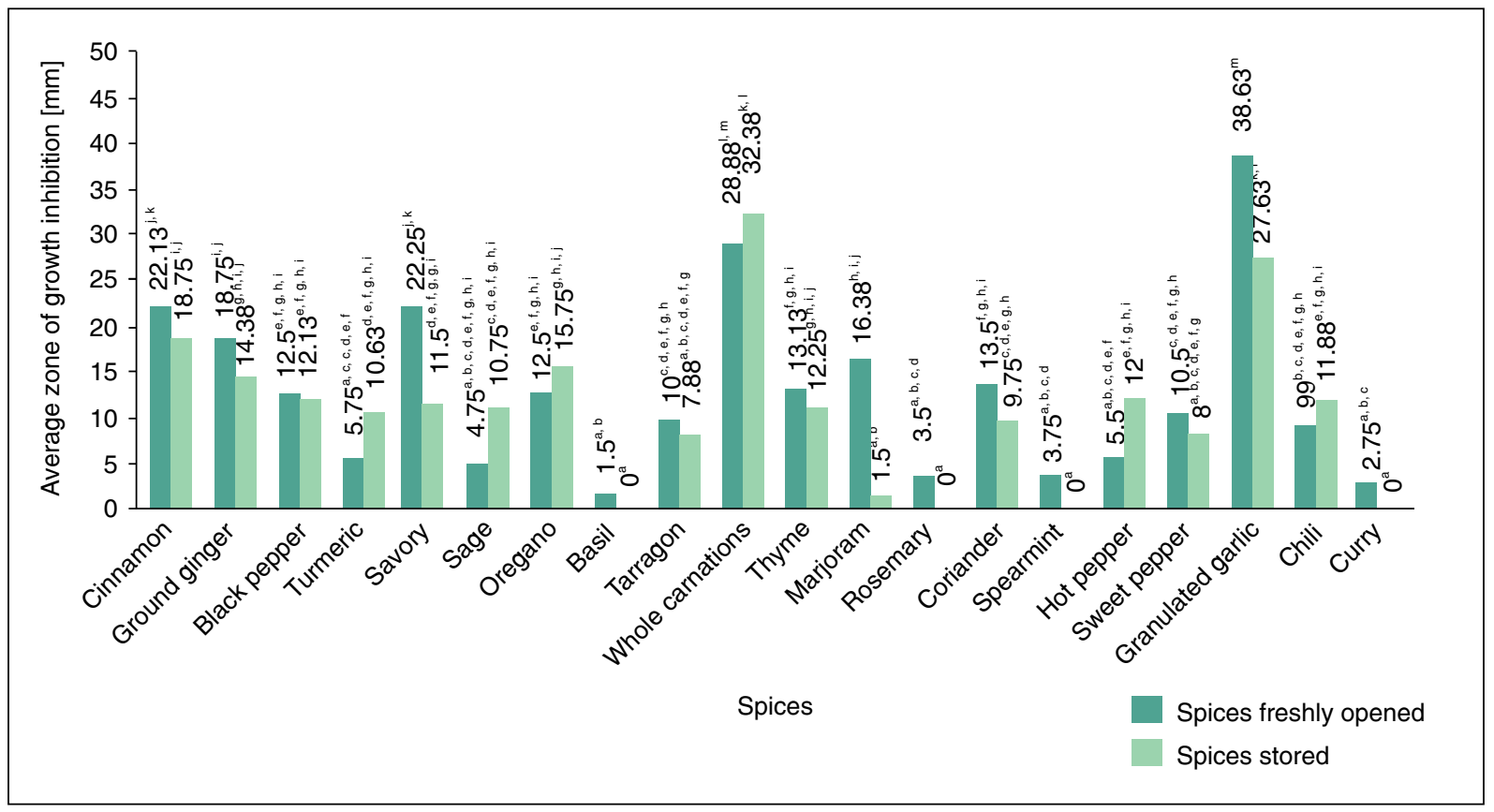

Figure 1. Mean zones of $L$. monocytogenes growth inhibition obtained with spices opened immediately before the test, and opened and stored for three months at room temperature $(a, b, c, \ldots .-$ means marked with different letters differ significantly)

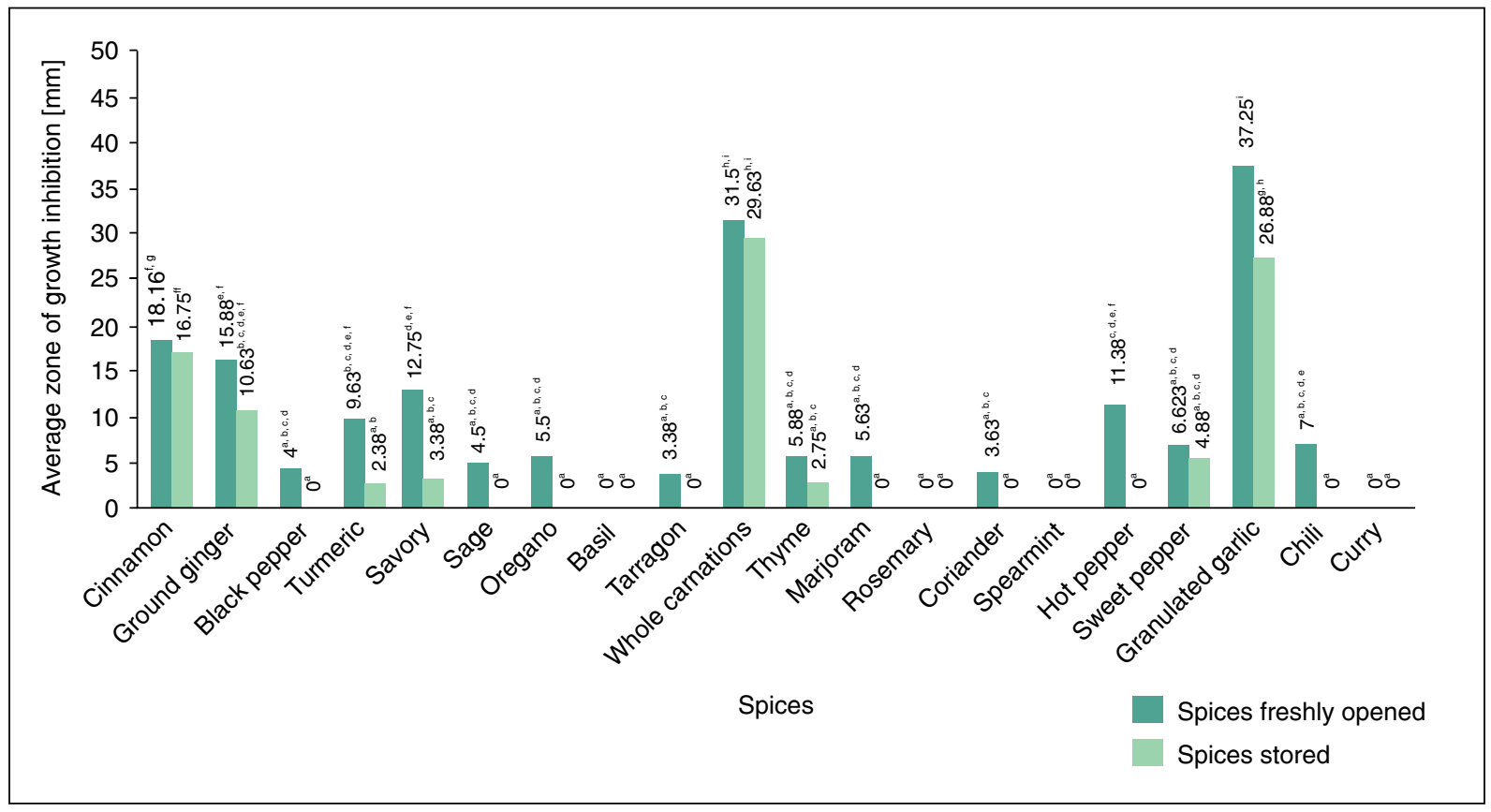

Figure 2. Mean zones of $S$. Enteritidis growth inhibition obtained with spices opened immediately before the test, and opened and stored for three months at room temperature $(a, b, c, \ldots-$ means marked with different letters differ significantly)

opened basil, rosemary and curry spices, there were no zones of $S$. Enteritidis growth inhibition detected (Fig. 2).

In the present study, no influence of the stored curry, rosemary, basil and green mint spices on L. monocy- togenes bacilli was reported (Fig. 1). In the group of stored spices, the highest activity against $L$. monocytogenes was found for: whole cloves $(33.38 \mathrm{~mm})$, granulated garlic $(27.63 \mathrm{~mm})$, ground cinnamon 
(18.75 $\mathrm{mm})$, oregano $(15.75 \mathrm{~mm})$, and ground ginger (14.38 mm) (Fig. 1). As for stored marjoram, activity against one $L$. monocytogenes strain was observed (Fig. 1). In the present study, in the group of stored spices, the activity against $S$. Enteritidis was demonstrated with whole cloves $(29.63 \mathrm{~mm})$, granulated garlic (26.88 $\mathrm{mm})$, ground cinnamon $(16.75 \mathrm{~mm})$, ground ginger (10.63 mm), sweet pepper (4.88 mm) ), savoury $(3.38 \mathrm{~mm})$, thyme $(2.75 \mathrm{~mm})$, and turmeric $(2.38 \mathrm{~mm})$ (Fig. 2). Significant differences in the spices tested three months after opening were found for cinnamon, ground black pepper, sage, oregano, basil, tarragon, marjoram, rosemary, coriander, green mint, hot pepper, chilli, and curry, which did not show antimicrobial activity against S. Enteritidis (Fig. 2).

Larger zones of $L$. monocytogenes growth inhibition were observed in the case of cloves $(32.38 \mathrm{~mm})$, oregano $(15.75 \mathrm{~mm})$, hot peppers $(12.00 \mathrm{~mm})$, chilli $(11.88 \mathrm{~mm})$, sage $10.75 \mathrm{~mm})$, and curcuma (10.63) spices tested three months after opening as compared to the spices opened immediately before the study (Fig. 1). As for S. Enteritidis, no differences in the antimicrobial activity were found between freshly opened and stored spices (Fig. 2).

The results of the microbiological purity evaluation of the herbs and spices used are shown in Table 1. A significant level of spices contamination was demonstrated, mostly with Bacillus species. The number of isolated fungi and molds was within the limits permitted by the Polish standard PN-A-86967: 1998/Az1: 2002 [8].

\section{Discussion}

Herbs and spices have been used for culinary purposes for centuries, but also in cosmetology and medicine. The antimicrobial properties of herbs are related to the presence of a number of chemical compounds [4].

In the own study, it was shown that granulated garlic suppressed the growth of $L$. monocytogenes and $S$. Enteritidis most strongly. Scientific research provides a lot of data on a wide range of garlic activity, which affects the survival of both Gram-positive and Gram-negative bacteria, including Escherichia, Salmonella, Staphylococcus, Streptococcus, Klebsiella, Proteus, Bacillus and Clostridium species (except $C$. botulinum) [4]. The own study also showed that ground cinnamon and whole cloves (both freshly opened and stored after opening) inhibited the growth of the tested strains. The direct antimicrobial activity of ground cinnamon and cloves against E. coli, S. aureus, Brochothrix thermosphacta, Lactobacillus rhamnosus and Pseudomonas fluorescens isolated from meat was presented by Kuanga et al. [9]. They showed that ground clove powder had a strong inhibitory effect on the five micro- organisms tested (MIC: $1.0 \% \mathrm{w} / \mathrm{v}-2.0 \% \mathrm{w} / \mathrm{v}$ ) [9]. On the other hand, Bayoub et al. [10] reported that clove extract was the most effective inhibitor of $L$. monocytogenes as compared to the other 12 plant extracts based on ethanol (MIC: $0.24 \mathrm{mg} / \mathrm{ml}$ ). In the own study, no influence of basil, curry rosemary (freshly opened spices) against $S$. Enteritidis. However, Weerakkody et al. [11] found that hexane rosemary extract showed a higher antibacterial activity than aqueous extracts in relation to all bacteria tested, except $S$. Typhimurium (MIC: $1.25-5.0 \mathrm{mg} / \mathrm{ml}$ ). Weerakkody et al. [11] also reported high activity of lemongrass, mountain pepper and rosemary against $S$. aureus, E. coli, S. Typhimurium and L. monocytogenes. Moreover, Sandasi et al. [12] found that basil, oregano, thyme, rosemary and ginger limited the mobility of $E$. coli 0157 : $\mathrm{H} 7$ and $P$. aeruginosa, while thyme and rosemary reduced the adhesion of $L$. monocytogenes cells to PVC (polyvinyl chloride), and thus, limited the biofilm development.

In the present study, no effect of curry, rosemary, basil and green mint (spices stored) on L. monocytogenes was found. Antibacterial activity of essential oils from oregano and thyme against $L$. monocytogenes and E. coli O157: $\mathrm{H} 7$ strains was demonstrated by Aboaba et al. [13] and Govaris et al. [14]. Also, Dimitrijevic et al. [15] demonstrated the effect of essential oils of thyme, rosemary and oregano against $L$. monocytogenes. Among the stored spices activities against $S$. Enteritidis was not shown for cinnamon, ground black pepper, sage, oregano, basil, tarragon, marjoram, rosemary, coriander, green mint, hot pepper, chilli and curry. On the other hand, Bayou et al. [10] found that cloves extract was the most effective inhibitor of $L$. monocytogenes as compared to the other 12 plant extracts based on ethanol (MIC: $0.24 \mathrm{mg} / \mathrm{ml}$ ). Babacan et al. [16] evaluated the antimicrobial effect of oregano extract on several Salmonella serotypes. Growth zones of 15 , 19 and $16 \mathrm{~mm}$-in-size were reported for $S$. Gallinarum, $S$. Enteritidis and $S$. Typhimurium, respectively [16]. However, de Medeiros Barbosa et al. [17] demonstrated the antibacterial effect of essential oils from oregano and rosemary against $E$. coli, $L$. monocytogenes and Salmonella spp. Al-Turki [18] described the antimicrobial action of hydrosols from five spice (thyme, peppermint, sage, black pepper and garlic) against $B$. subtilis and $S$. Enteritidis. The Author stated that garlic provided a stronger antibacterial effect against $B$. subtilis and $S$. Enteritidis in comparison with thyme, mint, sage and black pepper [18].

The assessment of microbiological purity of the tested spices, available on the Polish market, showed their significant contamination. Nevertheless, the results were within the limits allowed by the Polish Norm. Brużewicz and Malicki [19] evaluated the microbiological purity of herbs and spices on the Polish market. They found 
Table 1. Results of the microbiological purity evaluation of the spices investigated

\begin{tabular}{|c|c|c|c|c|c|c|}
\hline \multirow[t]{2}{*}{ Spice } & \multicolumn{3}{|c|}{$\begin{array}{l}\text { Spices tested immediately } \\
\text { after package opening }\end{array}$} & \multicolumn{3}{|c|}{$\begin{array}{l}\text { Spices tested three months } \\
\text { after package opening }\end{array}$} \\
\hline & TSA agar & $\begin{array}{l}\text { MacConkey } \\
\text { agar }\end{array}$ & $\begin{array}{l}\text { Sabourauda } \\
\text { agar }\end{array}$ & TSA agar & $\begin{array}{l}\text { MacConkey } \\
\text { agar }\end{array}$ & $\begin{array}{l}\text { Sabourauda } \\
\text { agar }\end{array}$ \\
\hline chili & + (1 colony $)$ & - & $+(1$ colony $)$ & $\begin{array}{l}+ \\
\text { Staphylococcus } \\
\text { camaieu }\end{array}$ & - & - \\
\hline hot pepper & $\begin{array}{l}+\left(\mathrm{uc}^{\star}\right) \\
\text { Bacillus pumilus }\end{array}$ & - & - & $\begin{array}{l}+ \\
\text { Bacillus pumilus, } \\
\text { Micrococcus luteus }\end{array}$ & - & - \\
\hline $\begin{array}{l}\text { sweet } \\
\text { pepper }\end{array}$ & - & - & - & - & - & $+(1$ colony $)$ \\
\hline curry & $\begin{array}{l}+ \text { (confluent growth) } \\
\text { Bacillus pumilus }\end{array}$ & - & $+(1$ colony $)$ & $\begin{array}{l}\text { + (approx. } 1000 \\
\text { colonies) } \\
\text { Paenibacillus viridis, } \\
\text { Bacillus clausii }\end{array}$ & - & - \\
\hline turmeric & + (1 colony $)$ & - & - & $\begin{array}{l}+ \\
\text { Staphylococcus } \\
\text { warneri }\end{array}$ & - & - \\
\hline cinnamon & - & - & - & $+(3$ colonies $)$ & - & - \\
\hline whole cloves & $s+(u c)$ & - & - & + (confluent growth) & $+(1$ colony $)$ & $+(1$ colony $)$ \\
\hline $\begin{array}{l}\text { ground } \\
\text { black } \\
\text { pepper }\end{array}$ & + (confluent growth) & - & - & + (confluent growth) & - & - \\
\hline $\begin{array}{l}\text { ground } \\
\text { ginger }\end{array}$ & $\begin{array}{l}+ \text { (confluent growth, } \\
\text { Bacillus pumilus) } \\
+ \text { (Lysinibacillus } \\
\text { fusimoris) }\end{array}$ & $+(2$ colonies $)$ & $+(3$ colonies $)$ & $\begin{array}{l}+ \text { (confluent growth) } \\
\text { Bacillus pumilus }\end{array}$ & - & - \\
\hline $\begin{array}{l}\text { granulated } \\
\text { garlic }\end{array}$ & $+(\mathrm{uc})$ & $+(1$ colony $)$ & - & $\begin{array}{l}+ \text { (confluent growth) } \\
\text { Bacillus pumilus }\end{array}$ & $\begin{array}{l}+(15 \text { colonies }) \\
\text { Escherichia } \\
\text { vulneris }\end{array}$ & - \\
\hline spearmint & - & - & - & + (3 colonies $)$ & - & - \\
\hline sage & $+(\mathrm{uc})$ & - & $+(4$ colonies $)$ & $\begin{array}{l}+ \text { (confluent growth) } \\
\text { Bacillus pumilus }\end{array}$ & $\begin{array}{l}+(2 \text { colonies }) \\
\text { Pantoea calida }\end{array}$ & $+(5$ colonies $)$ \\
\hline thyme & $\begin{array}{l}+ \text { (uc) } \\
\text { Bacillus licheniformis }\end{array}$ & - & - & $\begin{array}{l}+(20 \text { colonies }) \\
\text { Bacillus } \\
\text { licheniformis, } \\
\text { Bacillus pumilus }\end{array}$ & - & $+(1$ colony $)$ \\
\hline basil & $+(\mathrm{uc})$ & - & - & - & - & - \\
\hline oregano & $\begin{array}{l}+(\mathrm{uc}) \\
\text { Bacillus pumilus }\end{array}$ & - & $+(4$ colonies $)$ & - & - & - \\
\hline savory & $\begin{array}{l}+(6 \text { colonies }) \\
\text { Bacillus licheniformis }\end{array}$ & - & - & $\begin{array}{l}+ \text { (1 colony }) \\
\text { Bacillus } \\
\text { licheniformis }\end{array}$ & - & - \\
\hline marjoram & $\begin{array}{l}+(\mathrm{uc}) \\
\text { Bacillus licheniformis }\end{array}$ & & & + (confluent growth) & - & - \\
\hline tarragon & $\begin{array}{l}+(\mathrm{uc}) \\
\text { Bacillus pumilus }\end{array}$ & - & - & $\begin{array}{l}+ \text { (approx. } 600 \\
\text { colonies) } \\
\text { Bacillus simplex }\end{array}$ & - & - \\
\hline coriander & $\begin{array}{l}+(\mathrm{uc}) \\
\text { Bacillus pumilus }\end{array}$ & - & - & $\begin{array}{l}+(12 \text { colonies }) \\
\text { Bacillus pumilus, } \\
\text { Bacillus simplex }\end{array}$ & - & $+(4$ colonies $)$ \\
\hline rosemary & $\begin{array}{l}+(\mathrm{uc}) \\
\text { Bacillus pumilus }\end{array}$ & $\begin{array}{l}+ \text { (uc) } \\
\text { Pantoea } \\
\text { agglomerans }\end{array}$ & $+(5$ colonies $)$ & - & - & - \\
\hline
\end{tabular}


that the level of contamination with oxygen microflora and saprophytic fungi oscillated within the limits allowed by the Polish standard, at $10^{5} \mathrm{CFU} \times \mathrm{g}^{-1}$ and $10^{3} \mathrm{CFU} \times \mathrm{g}^{-1}$. The presence of $E$. coli and Salmonella, as well as coagulase-positive staphylococci, was detected in none of the samples tested. Based on the obtained data; related to the changes in the number of microorganisms noted during the storage period; the following product contamination categories were distinguished: 1) remained unchanged (pepper, nutmeg, basil), 2) decreased (garlic, onion, coriander, parsley, paprika, turmeric) or 3) increased (tomato) [19]. Lins [20] found that Salmonella spp. and coagulase-positive staphylococci were not detected in $25 \mathrm{~g}$ of the spices tested.

\section{Conclusions}

The antimicrobial activity of herbs and spices against L. monocytogenes and S. Enteritidis demonstrated in this study can be used in the food industry, e.g. for food preservation, minimizing the amount of chemical additives applied to the product and extending its shelf-life. Attention should be paid to the durability of herbs (active substances) during storage and the microbiological contamination of commercially available spices. It is important to broaden the research on the characteristics of active compounds in spices and herbs, and the mechanism of their action on microorganisms.

\section{Disclosure of interest: Authors declare no conflict of interest}

\section{Funding Sources}

This research was financially supported by the Nicolaus Copernicus University with funds from the maintenance of the research potential of the Department of Microbiology DS-UPB no. 782.

\section{References}

1. Martínez-Graciá C, González-Bermúdez C, Cabellero-Valcárcel A et al. Use of herbs and spices for food preservation: advantages and limitations. Current Opinion in Food Science. 2015; 6: 38-43, doi: 10.1016/j.cofs.2015.11.011

2. Prasad S, Gupta S, Aggarwal B. Micronutrients and Cancer: Add Spice to Your Life. Nutrition, Diet and Cancer. 2012: 23-48, doi: 10.1007/97894-007-2923-0 2.
3. Hyldgaard M, Mygind T, Meyer RL. Essential oils in food preservation: mode of action, synergies, and interactions with food matrix components. Front Microbiol. 2012; 3: 12, doi: 10.3389/fmicb.2012.00012, indexed in Pubmed: 22291693.

4. Leja KB, Czaczyk K. The industrial potential of herbs and spices a mini review. Acta Sci Pol Technol Aliment. 2016; 15(4): 353-365, doi: 10.17306/J.AFS.2016.4.34, indexed in Pubmed: 28071013.

5. Tajkarimi MM, Ibrahim SA, Cliver DO. Antimicrobial herb and spice compounds in food. Food Control. 2010; 21(9): 1199-1218, doi: 10.1016/j. foodcont.2010.02.003.

6. Tyagi AK, Malik A. Liquid and vapour-phase antifungal activities of selected essential oils against Candida albicans: microscopic observations and chemical characterization of Cymbopogon citratus. BMC Complement Altern Med. 2010; 10: 65, doi: 10.1186/1472-6882-10-65, indexed in Pubmed: 21067604.

7. Tyagi AK, Malik A. In situ SEM, TEM and AFM studies of the antimicrobial activity of lemon grass oil in liquid and vapour phase against Candida albicans. Micron. 2010; 41(7): 797-805, doi: 10.1016/j. micron.2010.05.007, indexed in Pubmed: 20541428.

8. Polska Norma, PN-A-86967:1998/Az1:2002. Przyprawy ziołowe-Mieszanki przyprawowe.

9. KUANG X, LI B, KUANG R, et al. GRANULARITY AND ANTIBACTERIAL ACTIVITIES OF ULTRA-FINE CINNAMON AND CLOVE POWDERS. Journal of Food Safety. 2011; 31(3): 291-296, doi: 10.1111/j.1745$-4565.2011 .00300 . x$.

10. Bayoub K, Baibai T, Retmane A, et al. Antibacterial activities of the crude ethanol extracts of medicinal plants against Listeria monocytogenes and some other pathogenic strains. Afr J Biotechnol. 2010; 9: 4251-4258.

11. Weerakkody N, Caffin N, Turner M, et al. In vitro antimicrobial activity of less-utilized spice and herb extracts against selected food-borne bacteria. Food Control. 2010; 21(10): 1408-1414, doi: 10.1016/j. foodcont.2010.04.014.

12. Sandasi M, Leonard CM, Viljoen AM. The in vitro antibiofilm activity of selected culinary herbs and medicinal plants against Listeria monocytogenes. Lett Appl Microbiol. 2010; 50(1): 30-35, doi: 10.1111/j.1472765X.2009.02747.x, indexed in Pubmed: 19874481.

13. . O, . S, . F. Antibacterial Effect of Edible Plant Extract on Escherichia coli 0157:H7. Pakistan Journal of Nutrition. 2006; 5(4): 325-327, doi: 10.3923/pjn.2006.325.327

14. Govaris A, Botsoglou E, Sergelidis D, et al. Antibacterial activity of oregano and thyme essential oils against Listeria monocytogenes and Escherichia coli O157:H7 in feta cheese packaged under modified atmosphere. LWT - Food Science and Technology. 2011; 44(4): 1240-1244, doi: 10.1016/j.Iwt.2010.09.022.

15. Dimitrijević S, Mihajlovski K, Antonović D, et al. A study of the synergistic antilisterial effects of a sub-lethal dose of lactic acid and essential oils from Thymus vulgaris $L$., Rosmarinus officinalis $L$. and Origanum vulgare L. Food Chemistry. 2007; 104(2): 774-782, doi: 10.1016/j. foodchem.2006.12.028.

16. Babacan O, Cengiz S, Akan M. Detection of antibacterial effect of oregano plant on various Salmonella serotypes. Ank Univ Vet Fak Derg. 2012; 59: 103-106.

17. Barbosa Id, Medeiros Jd, Oliveira Kde, et al. Efficacy of the combined application of oregano and rosemary essential oils for the control of Escherichia coli, Listeria monocytogenes and Salmonella Enteritidis in leafy vegetables. Food Control. 2016; 59: 468-477, doi: 10.1016/j. foodcont.2015.06.017.

18. Al-Turki Al. Antibacterial effect of thyme peppermint sage black pepper and garlic hydrosols against Bacillus subtilis and Salmonella enteritidis. J Food Agric Environ. 2007; 5: 92-94.

19. Brużewicz Sz, Malicki A. Stan mikrobiologiczny wybranych przypraw i przeżywalność w nich drobnoustrojów. ŻYWNOŚć. Nauka. Technologia. Jakość. 2007; 4(53): 99-108.

20. Lins P. Antimicrobial activities of spices and herbs against Salmonella Oranienburg. Food Control. 2018; 83: 123-130, doi: 10.1016/j.foodcont.2017.05.041. 